DOI : $10.14746 /$ rie.2020.14.26

\title{
Aleksandra Kruk, Konferencje monachijskie ds. bezpieczeństwa (2009-2019), Wydawnictwo Naukowe FNCE, Poznań 2020, ss. 298.
}

Monachijskie Konferencje ds. Bezpieczeństwa (MKB) to wiodące forum debat na temat międzynarodowej polityki bezpieczeństwa. Jak czytamy na stronie internetowej, MKB ,reprezentuje kompleksową koncepcję bezpieczeństwa, która obejmuje nie tylko tradycyjne kwestie bezpieczeństwa narodowego i międzynarodowego, ale także - między innymi - ekonomiczny, ekologiczny i ludzki wymiar bezpieczeństwa"1. Wśród polskich opracowań poświęconych szeroko pojętej problematyce niemcoznawczej brakowało dotychczas publikacji dotyczącej ww. konferencji.

Monografia Aleksandry Kruk została poświęcona wybranym aspektom organizowanych w latach 2009-2019 w Monachium konferencji (Münchner Sicherheitskonferenz). Autorka jednym z celów uczyniła ,...zbadanie, w jaki sposób uczestnicy definiowali podczas konferencji monachijskich międzynarodową rolę Niemiec oraz ustosunkowywali się do ważnych i aktualnych międzynarodowych problemów" (s. 11). Ponadto sformułowała następujące pytania badawcze (s. 11): Jak ocenia się działalność i skuteczność konferencji monachijskich? Czy uważa się, że są one ważną areną prezentowania poglądów, a ich aktorzy uczestniczą potem w jej pracach? Czy podczas konferencji odpowiednio kreowano wizerunek Niemiec? Punktem odniesienia dla sformułowanego problemu badawczego jest hipoteza: „[...] problematyka i agenda konferencji dążyły do odzwierciedlenia aktualnego dyskursu dotyczącego wyzwań w zakresie bezpieczeństwa międzynarodowego" (s. 11). Cezura czasowa zaproponowana przez Autorkę jest uzasadniona; analiza obejmuje lata 2009-2019, czyli okres przewodniczenia Monachijskim Konferencjom Bezpieczeństwa przez Wolfganga Ischingera, prawnika i byłego dyplomatę.

Omawiana publikacja składa się ze Wstępu, sześciu części [Geneza i kreatorzy konferencji monachijskich, Agenda konferencji monachijskich (2009-2019), Niemieckie koncepcje ról międzynarodowych na konferencjach monachijskich, Konferencje monachijskie jako narzędzie niemieckiej dyplomacji publicznej, Protesty przeciwko konferencjom ds. bezpieczeństwa w Monachium, Polska obecność na konferencjach w Monachium], Zakończenia i Bibliografii. Została ona ponadto opatrzona wykazem skrótów, indeksem nazwisk i streszczeniem w języku angielskim.

We Wstępie A. Kruk przedstawiła kolejno przedmiot badań, sformułowała pytania badawcze i określiła cezurę czasową, scharakteryzowała strukturę monografii i metody badawcze, a także dokonała krótkiego przeglądu podstawy źródłowej.

Problematyka monografii obejmuje w kolejnych częściach:

1) genezę konferencji („Pierwszy zjazd odbył się między 30 listopada a 2 grudnia 1963 roku w Hotelu Regina") i zaangażowania przewodniczących - Ewalda von Kleista (który jak pisze A. Kruk „był realistą, popierał rozwój zbrojeń konwencjonalnych oraz nuklearnych i zabiegał, by Niemcy mogli wraz z przedstawicielami z USA oraz innych państw dyskutować nad polityką bezpieczeństwa międzynarodowego", s. 23), Horsta Teltschika (którego osiągnięciem „było rozszerzenie formuły konferencji dzięki panelom dotyczącym wzrostu światowego znaczenia Azji”, s. 37) i Wolfganga Ischingera (kieruje organizowanymi konferencjami od 2008 r.) - w kształtowanie jej agendy. Przy czym w odniesieniu do tego

1 Über die Münchner Sicherheitskonferenz, https://securityconference.org/ueber-uns/ueber-die$\mathrm{msc} /, 30.06 .2020$. 
ostatniego Autorka koncentruje się szczególnie na jego stanowisku wobec konfliktu na Bałkanach, interwencji w Iraku w 2003 r. i Libii w 2011 r. oraz rosyjsko-ukraińskiego sporu o Krym;

2) przegląd agend konferencji w latach 2009-2019, w tym zwłaszcza takie kwestie, jak nowe wyzwania i zagrożenia bezpieczeństwa międzynarodowego oraz stosunki transatlantyckie, problem fake newsów i działań dezinformacyjnych, zmiany klimatyczne, kryzys migracyjny, bezpieczeństwo energetyczne i bezpieczeństwo w cyberprzestrzeni;

3) definiowanie roli Republiki Federalnej Niemiec w polityce międzynarodowej, poprzez m.in. przywołanie wypowiedzi niemieckich polityków na konferencjach w Monachium: Joschki Fischera, ministra spraw zagranicznych w rządach Gerharda Schrödera (koalicja SPD/ Sojusz 90/Zieloni, 1998-2005); Guido Westerwellego, ministra spraw zagranicznych w rządzie Angeli Merkel (koalicja CDU/CSU/FDP, 2009-2013), który był ,zwolennikiem polityki wstrzemięźliwości i umiaru”, s. 120; prezydenta RFN Joachima Gaucka (,apelowanie o «odpowiedzialność» było interpretowane jako przejście od «kultury powstrzymywania» w kierunku stania się «normalnym sojusznikiem». Dotychczas polityka powstrzymywania była traktowana jako filar wśród środków realizowania interesów bezpieczeństwa Niemiec. Rok 2014 był ważną cezurą, gdyż do wypowiedzi prezydenta J. Gaucka nawiązywało wielu polityków w Niemczech i poza granicami tego państwa. Prezydent postulował zwiększenie aktywności Niemiec i rozwiewał obawy, że nastąpi militaryzacja niemieckiej polityki zagranicznej”, s. 123); minister obrony Ursuli von der Leyen, która w 2014 r. mówiła o zwiększeniu ,zaangażowania Niemiec w wykonywanie roli przywódcy”, s. 127; oraz ministrów spraw zagranicznych w rządach Angeli Merkel (dwie koalicje CDU/CSU/SPD: 2013-2018, od 2018 r.): Franka-Waltera Steinmeiera popierającego zwiększenie zaangażowania się Niemiec w politykę międzynarodową, Sigmara Gabriela, który „podkreślił na konferencji w 2017 r., że Niemcy mogą pozytywnie kreować politykę międzynarodową na drodze europeizacji swojej polityki”, s. 137; i Heiko Maasa, który w lutym 2019 r. opowiadał się za „sojuszem multilateralistow” i współpracą transatlantycką, s. 138;

4) wpływ konferencji monachijskich na rozwój dyplomacji publicznej w Niemczech. Słuszne jest stwierdzenie A. Kruk, że „konferencje stały się ważnym, nietypowym elementem niemieckiej dyplomacji publicznej [...] są przedstawiane jako wydarzenia prywatne. Rola państwa niemieckiego jest jednak istotna, ponieważ uczestnikami konferencji są przedstawiciele instytucji rządowych i pozarządowych oraz osoby prywatne z wielu państw [...]" (s. 140). Co więcej, konferencje te ,zagwarantowały tworzenie rożnych struktur i gremiów dyskusyjnych, czerpiąc z tradycyjnych doświadczeń dyplomacji”, s. 143;

5) aktywność krytyków konferencji monachijskich (ukazywana poprzez pryzmat liderów, jak Tobias Pflüger i Claus Schreer, konferencji pokojowych w Monachium, demonstracji w centrum Monachium, Ośrodka Informacji ds. Militaryzacji obserwującego konferencje w Monachium, działający od 1996 r.). A. Kruk podkreśla, że „w przypadku Konferencji Monachijskich problematyka protestów dotyczyła zarówno spraw międzynarodowych, jak i państwowych. Przeciwnicy konferencji ds. bezpieczeństwa w Monachium organizowali protesty, w których wyrażali krytykę wobec niemieckich elit politycznych i wojskowych", s. 166. Protesty społeczne w Monachium przybierały trzy formy: konferencji pokojowych, forum prezentowania opinii aktywistów politycznych oraz manifestacji w centrum miasta;

6) aktywność polskich elit politycznych na konferencjach w Monachium, przekazy medialne oraz oceny i opinie polskich ekspertów.

Wnioski zawarte w Zakończeniu cechuje logiczna konsekwencja; sposób ich formułowania należy uznać za prawidłowy. A. Kruk odwołała się do aktualnego stanu badań, co znalazło odzwierciedlenie w zapisie bibliograficznym. Bibliografia jest istotnym elementem monografii (s. 236-285). Autorka przeprowadziła pogłębioną kwerendę obejmującą kluczowe dokumenty i opracowania, w tym archiwalia, wywiady, przemówienia, raporty, monografie i artykuły na- 
ukowe i publicystyczne, uzupełnione o materiały radiowe i telewizyjne, jak również materiały internetowe i informacje zamieszczane w mediach społecznościowych.

Podsumowując, Aleksandra Kruk przedstawiła ważny w sensie poznawczym i praktycznym problem badawczy, a monografia wypełnia lukę w polskich badaniach nad Monachijskimi Konferencjami ds. Bezpieczeństwa. Sposób prezentacji zagadnienia jest zgodny z przyjętymi założeniami; problem badawczy został ukazany całościowo (w ramach wybranej cezury czasowej - lata 2009-2019), pomimo przedstawiania niejednokrotnie kwestii szczegółowych.

BEATA MOLO

Krakowska Akademia im. Andrzeja Frycza Modrzewskiego 